\title{
ATHLETIC IDENTIFICATION OF WOULD-BE SPECIALISTS OF PHYSICAL EDUCATION AND SPORTS AT THE INSTITUTION OF HIGHER EDUCATION
}

\author{
Diana Karanauskienė, Kęstutis Kardelis, Laimutė Kardelienė \\ Lithuanian Academy of Physical Education, Kaunas, Lithuania
}

\begin{abstract}
Diana Karanauskienė. PhD in Social Sciences (Educational Science). Lecturer at the Department of Languages, Lithuanian Academy of Physi-
\end{abstract} cal Education. Research interests - students' social identifications in the institutions of higher education, qualitative research methodology.

\begin{abstract}
Athletic identification indicates the level of person's identification with a role of an athlete. Different levels of sports identifications are typical of all people: those who are sports professionals as well as those who only exercise. The students at the Lithuanian Academy of Physical Education (LAPE) are prepared to be sports coaches and teachers of physical education, and only some students choose the career of a professional athlete, so their identification with sports activities at the academy and their athletic identification might be rather different. The aim of the research was to reveal the manifestation of would-be physical education and sports specialists'athletic identification at the institution of higher education.

The empirical research involved the triangulation of qualitative and quantitative methods. The questionnaire was used to determine the general tendencies of the research participants'athletic identification, and the interview was meant to establish its content and specific features.

The research results have important implications for the personnel of the institutions of higher education attempting to facilitate student personal growth through participation in sports activities. The links of students'athletic identification with the variables in the higher school environment shows the presence of a pervasive athletic culture (Ferris et al., 2004) which results in the educational experience at the Academy. Athletic culture is experienced by students - athletes during their years of competitive, educational, and social development. Students - athletes'first contact with university environment is mediated through institutions - friends, coaches, practice and competitions. In some cases these factors increase athletes'satisfaction with collegiate experience and promote continued persistence toward a degree.

Research results let us conclude that athletic identification at the institution of higher education is determined by students' activity in sports, their sports aspirations and plans, evaluations of sporting conditions at the higher school and perception of the importance of sports activities. Athletic culture at the institution of higher education is both the precondition and the outcome of students'favorable athletic identification. Research revealed the links between the manifestation of students' athletic identification and the following sociodemographic and other factors: gender, academic achievements and academic identification, sports aspirations, living place, professional identification, feelings and the evaluation of their higher school.
\end{abstract}

Keywords: athletic identification, athletic culture, institution of higher education.

\section{INTRODUCTION}

$\mathrm{A}$ $\mathrm{t}$ the institutions of higher education academic personnel have been widely interested in the determinants of students' self perceptions as well as the degree to which such perceptions pervade various achievement domains. One of their viewpoints is that sport participation of students contributes to the perceptions in nonsport related areas. Research evidence suggests that participation in sports activities is related to greater prosocial attitudes among young people (Ryska, 2002). Studies attempting to link sport participa- tion to educational aspirations, popularity among peers, and academic identification have produced diverse results (Chandler, Goldberg, 1990; Sabo et al., 1993). Though sport involvement might have significant potential impact on the perceptions, attitudes and behaviors of students, little empirical research is carried out regarding how the nature of higher school sport experience may impact other experiences and perceptions among its participants. Initial sport research indicates that the athletic role constitutes a meaningful dimension of self-identity 
and influences various responses of athletes and non-athletes alike (Brewer et al., 1993). An individual with a strong athletic identity would be more likely to interpret sport - related events in terms of how they impact his or her athletic functioning. However, considerably less is known regarding the potential role of athletic identity on the formation of perceptions outside the sport setting (Ryska, 2002). S. Stryker (1978, cit. from Ryska, 2002) originally proposed that greater identification with a particular self -identity dimension increases the tendency for an individual to use the perceptual and emotional aspects of the particular dimension to interpret and respond to situations within other identity — based dimensions.

Athletic identification indicates the level of person's identification with a role of an athlete. Different levels of sports identifications are typical of all people: those who are sports professionals as well as those who only exercise. The students at the Lithuanian Academy of Physical Education (LAPE) are prepared to be sports coaches and teachers of physical education, and only some students choose the career of a professional athlete, so their identification with sports activities at the academy and their athletic identification might be rather different. As Adler and Adler (1994) suggest, athletic career starts with the innocent involvement in games, recreational activities, and it continues up to competitive, and then to professional sport. Though all children play games, very few of them become professional athletes. However, athletic identification is characteristic of people actively engaged in sports, as well of people who only exercise.

Rather than simply comparing the levels of personal identifications between athletes, proper inquiry into this relationship should include a description of the student - athlete's identification with sport (Griffin, 1998, cit. from Ryska, 2002). Thus, the aim of the research was to reveal the manifestation of would-be physical education and sports specialists' athletic identification at the institution of higher education.

\section{METHODS}

The empirical research involved the triangulation of qualitative and quantitative methods. The questionnaire was used to determine the general tendencies of the research participants' athletic identification, and the interview was meant to establish its content and specific features.

Students' athletic identification was measured applying a scale which was composed on the basis of research on athletic identification (Brewer et al., 1993; Ryska, 2002; Anderson, 2004), as well as students' interview responses. The internal consistency - Cronbach's alpha - of the athletic identification scale was adequate $(0.64)$. It means that the method was valid to measure athletic identification. Other questionnaire questions were meant to evaluate students' sociodemographic indicators, academic achievements and environmental variables. Students' academic achievements were self-reported measures. Statistical data analysis was performed using the package SPSS 11.0 for Windows.

The semi-structured interview involved questions reflecting the manifestation of athletic identification introduced in research (Brewer et al., 1993; Murphy et al., 1996; Wiechman, Williams, 1997; Webb et al., 1998). The qualitative content analysis (Strauss, Corbin, 1998), based on interpretation, was used to define students' interaction, motivation and perceptions in the context of the institution of higher education. As we seek to present a holistic view of the researched phenomenon, the qualitative and quantitative data were presented together.

The sample in the quantitative research consisted of 622 ( 366 boys and 256 girls) $1-4^{\text {th }}$ year students at the Lithuanian Academy of Physical Education. The interview participants were 54 students of the same institution.

\section{RESULTS}

Different sporting activity of students might influence their athletic identification. According to the research data $39.4 \%$ of the research participants attended training sessions and sought for sports results. Almost the same number of students (36.7\%) went to training sessions, but they did not need sports results, and $23.5 \%$ of the researched students went to sports classes included in the curriculum. It is quite natural that $74.7 \%$ of those who sought for sports results were would-be sports coaches, and only $25.3 \%$ - teachers of physical education. Sports sessions without seeking for sports results were attended almost by the same number of students of both specialities: $46.1 \%$ of them were would-be teachers of physical education, and $53.9 \%$ - sports coaches. Among those, who only attended sports classes according to the curriculum, $66.7 \%$ were would-be teachers of physical education, and $33.3 \%$ - sports coaches. 


\begin{tabular}{|l|}
\hline Favorable factors for athletic identification \\
- Possibility to increase physical fitness \\
- Possibility to fortify health \\
- Possibility to relax after intensive mental work \\
- Possibility to try many branches of sport \\
- Possibility to study theoretical aspects of sports \\
- Possibility to match studies with active participation in sports \\
- Sports camps \\
- Enough time for training sessions
\end{tabular}

The research established the links between sports activity and sports aspirations. As many as $29.6 \%$ of the research participants claimed that their aim of studies at LAPE was to become a good sportsman / sportswoman, though $40.6 \%$ disagreed with that, and 28.9 were not sure about that. The majority of the researched students $(56 \%)$ were sure that it was obligatory to attend training sessions while studying at the academy, but $24.5 \%$ of students claimed it was optional. Even $17.7 \%$ of the respondents suggested that good sports results at this higher school were more important than good learning. Though 55.8\% did not agree with such a statement, and $25.5 \%$ were not sure. However, $28.6 \%$ of students thought that a good sportsman could be a good student ( $40.8 \%$ disagreed). It is worth noting that though no significant differences were found between respondents' specialities and the years of studies in evaluating their athletic identification, there was a tendency that as the years went by studies became more important than sports aspirations.

In the interview all students despite their sports activity were positive about their sports experience at the academy, but their opinions differed about the amount of sports theory. All the respondents who were active in training sessions and needed sports results indicated that most of all they appreciated the possibilities to match their studies with intensive sports training sessions. To many of them it was the main motivating factor of choosing this higher school because they were capacitated to go to sports camps and to spend much time on training. They suggested that however hard it was to train, the experience was rewarding, interesting, and meaningful. The students felt adverse that at some periods of time (before competitions, etc.) they had too many training sessions (even at weekends), and they did not have enough time for learning. Some of them resented that not always the conclusions of the medical examination or the injuries and traumas of students were heeded. Thus,
Unfavorable factors for athletic identification (given by some of the students)

- Too much sports theory

- Too intensive training sessions before competitions

- The sports work load is too high, and it interferes with learning

- Sometimes the students' traumas and the conclusions of their medical examination are not taken into account

students' identification with sports at the academy could be influenced by various factors (Table).

The students' opinion imparted in the interview suggests that despite some unfavorable factors the conditions for sports activities and their organization in the academy encouraged students' identification with sports activities which in its turn strengthened their athletic identification in general. All the respondents agreed that sport was very important in their lives and that every student at the academy had to go in for some branch of sport. But when participation in sports was compared to learning, their opinions diverged: some students (mostly those who were actively engaged in sports) preferred sports to learning, others - learning to sports, claiming that however important sport was to the would-be specialists of physical education and sports, it should not be their priority or interfere with their learning. The factor analysis of Athletic Identification Scale confirmed this fact. It revealed two factors with the eigenvalues of 1.0 or better. The first factor could be characterized by sports priority over learning (factor loading was 0.82 , Cronbach's alpha - 0.70). The most important features of this factor were the wish to become a good sportsman / sportswoman (0.84), and the greater importance of sports results compared to learning outcomes $(0.80)$. The second factor $(0.89)$ can be described by the preference of learning to active participation in sports. The exclusive feature of this factor was the students' attitude that sports should not interfere with learning other subjects.

The significance of those factors was confirmed comparing them with the manifestation of academic identification of the research participants. The first factor (giving prominence to sports) was more typical of students expressing lower levels of academic identification. More students whose academic identification was weaker compared to those with higher academic identification claimed that good sports results were more valuable than academic achievements (23.2 and $12.1 \%$ of students 
respectively; $\mathrm{p}<0.001$ ), and a good student first of all was a good sportsman / sportswoman (33.6 and $24.8 \% ; \mathrm{p}<0.01$ ). The second factor (priority of learning over participation in sports) was more common of students manifesting higher academic identification (56.8 and 43.8\%, $\mathrm{p}<0.05$ ).

As it was mentioned before, students expressing higher academic identification had better grades at the higher school, and they had been better students at the secondary school, as well. Thus we can suppose that students with stronger athletic identification should not have been successful at their studies as their academic identification was weaker. The supposition was confirmed by this study. Inclination for sports was more characteristic of students who had adequate and good grades at the secondary school and less characteristic of those whose grades were very good and excellent (respectively 83.2 and $8.1 \%, p<0.001$ ), accordingly it was more characteristic of those students who had adequate and good grades at the academy and less characteristic of those whose grades at this higher school were very good and excellent (67.8 and $13.4 \%, \mathrm{p}<0.005$ ). Thus we can draw a conclusion that students who prefer sports activities over learning manifest lower academic identification and have poorer grades at the academy.

The first factor (preferring sports activities over studies) was more characteristic of those students who chose to study at the academy because of their fondness of sports compared to those to whom sport was not the main reason to enter this higher school (respectively 27 and $18 \%, \mathrm{p}<0.05$ ). It should be noted that students who believed that the academy should soon become a modern sports university, compared to those who had some doubts about that, were more inclined for sports than learning ( 31.1 and $19.9 \%, \mathrm{p}<0.005)$.

It is worth noting that students expressing stronger athletic identification had more favorable attitudes towards their future profession - to teach and to train children. Compared to other students they believed that their profession was as prestigious as of teachers of other subjects (45.1 and $26.1 \%, \mathrm{p}<0.001)$, and they less agreed with the idea that children could learn polite behavior during the lessons of more serious subjects, but not physical education ( 60.8 and $21.5 \%, \mathrm{p}<0.05)$. It is interesting to note that students with higher athletic identification believed that teachers of physical education and coaches had to do research (88.2 and 3.3\%, p < 0.05). We can conclude that students expressing stronger athletic identification are more inclined to identify themselves with their future profession.

It should also be noted that students who were more apt to their sports activities felt better at the academy. More of them were proud that they studied at the LAPE (respectively 77.7 and 3.3\%, $\mathrm{p}<0.001$ ), and more of them would choose the same higher school if they had to (82.9 and 2.0\%, $\mathrm{p}<0.001)$. They also more cared about the image of the academy (50.3 and $18.3 \%, \mathrm{p}<0.05)$, and they were inclined to associate their success with the success of the academy $(61.2$ and $9.1 \%$, $\mathrm{p}<0.01$ ), more of them did not hesitate to tell others that they studied at this higher school $(82.3$ and $9.8 \%, p<0.05)$. Besides, more of them were sure they did not waste their time at the academy $(87.6$ and $5.2 \%, \mathrm{p}<0.05)$ and that they felt safe (62.1 and $16.4 \%, \mathrm{p}<0.05)$.

Students with stronger academic identification not only felt better at the academy, but they evaluated it more favorably, too. More of them believed that conditions to learn there were good enough, if you were able to make use of them $(86.3$ and $2.0 \%$, $\mathrm{p}<0.005$ ). They were also satisfied with the relations with teachers $(48.7$ and $10.5 \%, \mathrm{p}<0.005)$ and other students $(64.4 \%$, compared to those $14.5 \%$ who were not satisfied, $\mathrm{p}<0.01)$. More of them believed that the academy was the place to be engaged in serious research $(59.9$ and $8.6 \%, \mathrm{p}<0.001)$, and that it was now worth the name of a modern university $(63.1$ and $11.9 \%, \mathrm{p}<0.001)$. However, more of them were not satisfied with the services of the academy library $(48.7 \%$, compared to the $14.2 \%$ of satisfied students, $\mathrm{p}<0.005$ ).

The research established sports identification differences according to the students' gender. As it was expected, sports identification was more characteristic of male students than female students $(70.4$ and $29.6 \%, p<0.01)$. It was also noticed that stronger sports identification was expressed by students from cities compared to those who had arrived from small towns (respectively 68 and $32 \%, \mathrm{p}<0.001$ ). Besides, higher levels of sports identification were manifested by students who did not have to work while studying ( 85.3 and $14.7 \%, \mathrm{p}<0.05)$ and who did not have to pay for their studies $(83.2$ and $16.8 \%, \mathrm{p}<0.05)$.

\section{DISCUSSION}

The research results have important implications for the personnel of the institutions of higher education attempting to facilitate student 
personal growth through participation in sports activities.

Athletic identification of students is a specific trait of the Academy. The relations between the manifestation of students' athletic identification and other variables, revealed in this study, are important with regard to education. In the conte$\mathrm{xt}$ of the institution of higher education the data between students' sports aspirations and academic identification are of great importance. The present research indicated that sports activities oriented students towards sports achievements and that could have a negative impact on the processes of their academic identification because students actively engaged in sports usually manifest lower levels of academic identification, and thus lower academic achievements. Many of them had lower grades in their secondary school, too. For many of the sporting students the possibility to match high sports aspirations and studies was almost the only possibility to acquire higher university education. Besides, students could enter the Academy not so much for their academic credentials, but for their athletic abilities. So, having entered the Academy, students have problems with their studies not only because of their poor academic preparation, but also for their lack of motivation to put maximal efforts in learning. Other studies also revealed that strong identification with the athletic role contributed to poor academic achievements (Cornelius, 1995). The data of another research with the students of the Academy (Kardelis, Karanauskiene, 2003) indicated that as many as $62 \%$ of the research participants, demonstrating lower levels of academic identification, chose their studies at the Academy because of haphazard reasons related to sports activities (various exemptions for students - athletes, less difficult studies compared to other universities, etc.), i. e. without intrinsic motivation.

As it was mentioned above, the links between students' sports and academic aspirations are promiscuous. Research data by E. Snyder and E. Spreitzer (1981, cit. from Ryska, Vestal, 2004) showed that students who were members of college sports teams, had better grades and set higher academic goals for themselves compared to students who were not involved in sports activities. We cannot disagree with E. Geron (1996) that participation in sports develops character and behavioral traits which condition good learning. However, F. Blann (1985) found that students actively engaged in sports did not have necessary learning skills, and their academic and career plans were not mature enough. As we see, this problem area has many unanswered questions. More research in the ratio of athletic and academic identification would help to improve the quality of studies of students who are planning their careers connected with sports.

The links of students' athletic identification with other variables in the higher school environment shows the presence of a pervasive athletic culture (Ferris et al., 2004) which results in the educational experience at the Academy. According to the authors, athletic culture is experienced by students - athletes during their years of competitive, educational, and social development. Unlike many of their peers, students - athletes' first contact with university environment is mediated through institutions - teammates, coaches, practice and competitions - with which they are generally familiar. When affective, these factors increase athletes' satisfaction with collegiate experience and promote continued persistence toward a degree.

\section{CONCLUSIONS}

1. Athletic identification at the institution of higher education is determined by students' activity in sports, their sports aspirations and plans, evaluations of sporting conditions at the higher school and perception of the importance of sports activities.

2. Athletic culture at the institution of higher education is both the precondition and outcome of students' favorable athletic identification.

3 . The present research revealed the links between the manifestation of students' athletic identification and the following sociodemographic and other factors: gender, academic achievements and academic identification, sports aspirations, living place, professional identification, feelings and the evaluation of their higher school.

\section{REFERENCES}

Adler, P. A., Adler, P. (1994). Social reproduction and the corporate other. The institutionalization of afterschool activities. The Sociological Quarterly, 35, 309-328.

Anderson, C. B. (2004). Athletic identity and its relation to exercise behavior: Scale development and initial vali- dation. Journal of Sport and Exercise Psychology, 26 (1), $39-57$.

Blann, F. W. (1985). Intercollegiate competition and students' educational career plans. Journal of College Student Personnel, 26, 115-118. 
Brewer, B. W., Van Raalte, J. L., Linder, D. E. (1993). Athletic identity: Hercules' Muscles or Achiles' Heel? International Journal of Sport Psychology, 24, 237-254.

Chandler, T. J., Goldberg, A. D. (1990). The academic all - American as vaunted adolescent role identity. Sociology of Sport Journal, 7, 287-293.

Cornelius, A. (1995). The relationship between athletic identity, peer and faculty socialization, and college student development. Journal of College Student Development, $36,560-573$.

Ferris, E., Finster, M., McDonald, D. (2004). Academic fit of student - athletes: An analysis of NCAA division I - A graduation rates. Research in Higher Education, 45 (6), 555-575.

Geron, E. (1996). Intelligence of child and adolescent participation in sports. In The Child and Adolescent Athlete. Illinois: Human Kinetics Books.

Kardelis, K., Karanauskienė, D. (2003). Studentų suvokto aukštosios mokyklos identiteto bei ívaizdžio ir jų veiklos motyvacijos sąsaja. Ugdymas. Küno kultūra. Sportas, 4 (49), 25-30.

Murphy, G. M., Petitpas, A. J., Brewer, B. W. (1996). Identity foreclosure, athletic identity, and career maturity in intercollegiate athletes. The Sport Psychologist, 10, 239-246.

Ryska, T. A. (2002). The effects of athletic identity and motivational goals on global competence perceptions of students - athletes. Child Study Journal, 32 (2), 109-129.

Ryska, T. A., Vestal, S. (2004). Effects of sport motivation on academic strategies and attitudes among high school student - athletes. North American Journal of Psychology, 6 (1), 101-120.

Sabo, D., Melnick, M. J., Vanfossen, B. E. (1993). High school athletic participation and postsecondary educational and occupational mobility: A focus on race and gender. Sociology of Sport Journal, 2, 195-209.

Strauss, A. L., Corbin, J. (1998). Basics of Qualitative Research: Techniques and Procedures for Developing Grounded Theory. Thousand Oaks: Sage.

Webb, W. M., Nasco, S. A., Riley, S., Headric, B. (1998). Athlete identity and reactions to retirement from sports. Journal of Sport Behavior, 21 (3), 338-363.

Wiechman, S. A., Wiliams, J. (1997). Relation of athletic identity to injury and mood disturbance. Journal of Sport Behavior, 20 (2), 199-208.

\title{
BŪSIMŲJŲ KŪNO KULTŪROS IR SPORTO SPECIALISTŲ SPORTINE் IDENTIFIKACIJA AUKŠTOJOJE MOKYKLOJE
}

\author{
Diana Karanauskienė, Kęstutis Kardelis, Laimutė Kardelienė \\ Lietuvos kūno kultūros akademija, Kaunas, Lietuva
}

\section{SANTRAUKA}

Sportinè identifikacija rodo, kokiu lygmeniu asmuo identifikuoja save su sportininko vaidmeniu. İvairūs sportinès identifikacijos lygmenys būdingi visiems žmonėms: sportininkams profesionalams ir tiems, kurie tik mankštinasi. Lietuvos kūno kultūros akademijoje studentai rengiami dirbti sporto šakos treneriais, kūno kultūros mokytojais, ir tik kai kurie iš jų renkasi profesionalaus sportininko karjerą, todèl jų sportinè identifikacija šioje aukštojoje mokykloje gali būti labai skirtinga. Tyrimo tikslas — atskleisti būsimujų kūno kultūros ir sporto specialistų sportinès identifikacijos raišką aukštojoje mokykloje.

Empirinio tyrimo metu buvo taikoma tyrimo metodų trianguliacija, kokybiniai ir kiekybiniai tyrimo metodai. Apklausa raštu buvo stengiamasi išsiaiškinti bendresnes tyrimo dalyvių nuostatas ir tendencijas. Taikant interviu metodą siekta nustatyti sportinès identifikacijos turini ir raiškos specifiką.

Tyrimo rezultatai reikšmingi aukštosios mokyklos dèstytojams, kurie rūpinasi, kaip skatinti studentų tobulèjimą jiems dalyvaujant sportinèje veikloje. Sportinès studentų identifikacijos sąsajos su aukštosios mokyklos aplinkos veiksniais parodo esamą sporto kultūrą, kuri turi įtakos studijoms Akademijoje. Sporto kultūrą studentai patiria visą laiką savo varžybineje, studiju ir asmeninio tobulejjimo veikloje. Aukštosios mokyklos aplinkoje sporto kultūros tarpininkai būna draugai, treneriai, varžovai, teisèjai. Kai kuriais atvejais sporto kultūra ugdo studentų teigiamus jausmus studijų procese ir skatina stengtis.

Tyrimo rezultatai leidžia daryti išvadą, kad sportinę studentų identifikaciją lemia studentų aktyvumas sportinėje veikloje, jų sportiniai siekiai ir planai, sąlygų sportuoti aukštojoje mokykloje ivvertinimas, savo sportinès veiklos suvokimas. Sporto kultūra aukštojoje mokykloje yra ir būtina palankios sportinès identifikacijos sąlyga, ir jos rezultatas. Tyrimas atskleide sportinès identifikacijos raiškos sasajas su tiriamujų lytimi, studiju pasiekimais, akademine identifikacija, profesine identifikacija, gyvenamaja vieta ir tuo, kaip studentai jaučiasi aukštojoje mokykloje, kaip ją vertina.

Raktažodžiai: sportinė identifikacija, sporto kultūra, aukštoji mokykla.

Gauta 2007 m. gegužès 30 d.

Received on May 30, 2007

Priimta $2007 \mathrm{~m}$. rugsejjo $19 \mathrm{~d}$.

Accepted on September 19, 2007
Diana Karanauskienè

Lithuanian Academy of Physical Education

(Lietuvos kūno kultūros akademija)

Sporto str. 6, LT-44221 Kaunas

Lithuania (Lietuva)

Tel +370 37302663

E-mail d.karanauskiene@lkka.1t 